Aim of the study: To present the changes in the incidence of cancers of the head and neck organs in south-eastern Poland and in the whole country in the years 1990-2012.

Material and methods: A retrospective analysis the incidence of cancers of the head and neck organs in south-eastern Poland in the years 1990-2012. Statistical methods used for cancers of ICD-10 COO-C14 and C30-C32.

Results: For Poland, the absolute number of cases was 123,120 in the years 1990-2012. For males, the number of cases per year increased from 4468 in 1990 to 4953 in 2012, and for females from 816 to 1442 .

The percentage share of tumours of the head and neck in all malignant tumours decreased from $10.0 \%$ to $6.5 \%$ for males and from $2.1 \%$ to $1.9 \%$ for females.

In the years 1990-2012 in south-eastern Poland, for males, the absolute number of cases per year decreased from 335 in 1990 to 286 in 2012. For females, a minimal increase in cases was from 63 to 64 cases. The percentage share of tumours of the head and neck in all malignant tumours decreased from $12.2 \%$ to $6.7 \%$ for males and from $2.7 \%$ to $1.8 \%$ for females.

Conclusions: Incidences of cancers of the head and neck organs in Poland have seen a slight upward trend in the absolute number of cases over the last two decades. In Poland a decrease in the incidence of cancer of the larynx was reported, with an increase in the incidence of oropharyngeal cancer.

Key words: head and neck cancer, cancer epidemiology.

Contemp Oncol (Pozn) 2017; 21 (1): 77-82 DOI: https://doi.org/105114/wo.2017.66497

\section{Comparative analysis of the incidence of head and neck cancer in south-eastern Poland and in Poland in the years 1990-2012}

\author{
Jan Gawełko ${ }^{1}$, Marek Cierpiał-Wolan ${ }^{2}$, Andrzej Kawecki ${ }^{1}$, Konrad Wilk ${ }^{3}$, \\ Danuta B. Pięciak-Kotlarz ${ }^{4}$, Damian Sikorski ${ }^{5}$ \\ ${ }^{1}$ University of Rzeszow, Rzeszow, Poland \\ ${ }^{2}$ Provincial Statistical Office, Rzeszow, Poland \\ ${ }^{3}$ Regional Clinical Hospital No. 1, Rzeszow, Poland \\ ${ }^{4}$ Department of Nursing, Institute of Nursing and Health Sciences, Medical Faculty, \\ University of Rzeszow, Rzeszow, Poland \\ ${ }^{5}$ Clinical Department of Radiotherapy, Voivodship Hospital No. 1, Rzeszow, Poland
}

\section{Introduction}

Head and neck cancers (HNCA) invariably constitute a significant epidemiological and clinical problem in Poland and in other countries. Definitely, the most common cancer in this region is squamous cell carcinoma [1, 2].

The incidence of head and neck squamous cell carcinoma (HNSCC) is determined by the degree of exposure of a population to well-defined carcinogens, whose impact in the social scale has undergone considerable changes over the last decade. The carcinogenic importance of exposure to cigarette smoke has become less important, whereas the role of infection with Human Papilloma Virus (HPV) has grown, which translates into changes in the structure of the incidence rate [3-10].

HNCAs were the sixth most common group of malignant neoplasms among males and twelfth among females in Poland in 2012 [11]. There are a number of differences in the epidemiology of these tumours in south-eastern Poland, which differentiate it from the national data.

In 1990, in south-eastern Poland, HNCA with 398 cases accounted for $7.9 \%$ of all cancers, and in Poland the figures were 5284 and $6.3 \%$, respectively [12]. In subsequent years a significant change in these proportions was recorded, caused by a gradual decline in the incidence in absolute numbers in south-eastern Poland, with a growth nationwide. In 2012, 350 cases were recorded in the region, which accounted for $4.3 \%$ of all malignant tumours, and for Poland these figures were 6395 and $4.2 \%$, respectively [11-13]. It is noteworthy that there was a percentage decrease in HNCA among all malignant tumours, which is contrary to some opinions expressed by related professionals and in the media.

The aim of the paper was to present in detail the changes in the incidence of HNCA in south-eastern Poland and in the whole country in the years 1990-2012.

\section{Material and methods}

A retrospective analysis was carried out of the incidence of cancers of the head and neck organs in south-eastern Poland in the years 1990-2012. In the years 1990-1998 south-eastern Poland was defined as the area of the former voivodships of Krosno, Przemysl, Rzeszow, and Tarnobrzeg, and in the period since 1999 as an area of Podkarpackie Voivodship. 
Using standard statistical methods, crude rates and structure indicators (percentage) have been calculated for cancers of ICD-10 C00-C14 and C30-C32 sites, based on demographic data of Voivodship Statistical Office (WUS) and Podkarpackie Cancer Registry in Rzeszow.

Based on published reports of the Department of Epidemiology of the Oncology Centre of the Maria Skłodowska-Curie Institute of Oncology in Warsaw, similar data for Poland has been compiled in order to objectively compare the structure of the incidence.

Due to a failure to fill in statistical documents in protest of Health Care in the years 1997-1998 there is no data on the incidence of cancer in this period.

\section{Results}

In the years 1990-2012 a total of 6516 cases of malignant tumours of the head and neck organs were registered in south-eastern Poland, including 5403 cases for males and 1113 for females. For males, the absolute number of cases per year decreased from 335 in 1990 to 286 in 2012. For females, a minimal increase in cases was reported and the values were 63 and 64 cases, respectively.

Crude incidence rates for males during a 21-year period of analysis decreased from 30.8/100 thousand in 1990 to $27.5 / 100$ thousand in 2012, while for females they increased from 5.5/100 thousand to 5.9/100 thousand respectively. In the years 1990-2012, the percentage share of tumours of the head and neck in all malignant tumours decreased from $12.2 \%$ to $6.7 \%$ for males and from $2.7 \%$ to $1.8 \%$ for females. Table 1 and Figs. $1-3$ show data for individual years of the analysis.

For Poland, the absolute number of cases in total was 123,120 in the years 1990-2012, including 99,797 cases for males and 23,323 for females. For males, the number of cases per year increased from 4468 in 1990 to 4953 in 2012, and for females from 816 to 1442 respectively. Crude incidence rates for males were 24.1/100 thousand in 1990 and 25.5/100 thousand in 2012. For women, the corresponding values were $4.2 / 100$ thousand and $7.0 / 100$ thousand. The percentage share of tumours of the head and neck in all malignant tumours decreased from $10.0 \%$ to $6.5 \%$ for males and from $2.1 \%$ to $1.9 \%$ for females. Table 1 and Figs. 4-8 show detailed data for individual years.

\section{Discussion}

The analysis of the incidence of tumours of the head and neck organs nationwide over the last two decades between 1990 and 2012 shows a slight upward trend in the absolute number of cases per year and, at the same time, a marked reduction in the percentage share of this group among all malignant tumours. The latter phenomenon is the result of a clear parallel increase in the incidence of cancers in total, with a limited increase in the number of cases of cancers of the head and neck organs, and even stabilisation from the mid-90s [11, 12, 14]. Similar data apply to south-eastern Poland, but the decline in the percentage share of cancers of the head and neck organs, primarily related to the group of males, is even more spectacular. The findings of epidemiological studies are in clear contradiction to the popular opinion about the "epidemic of cancers of the head and neck" $[12,13,15]$. In fact, this is not the case.

In the years 1963-2012, in south-eastern Poland, they ranked sixth with 13,654 cases, including 11,362 cases for males and 2,282 cases for females. In the same period, at the country level, they ranked seventh with 233,132 cases in total, including 194,009 cases for males and 39,123 cases for females. The peak incidence, both for males and females, was recorded in south-eastern Poland in 1990. For Poland, the peak incidence for males was recorded in 1993 whereas the increase in the incidence among females has continued [11-15]. It should be noted, however, that there are distinct changes in the structure of incidence depending on the location of the primary tumour.

Over the past two decades, south-eastern Poland has recorded a reduction in the total incidence of cancers of the lip, gums, palate, other parts of the oral cavity, oropharynx, and above all larynx, which was and remains the most common location of cancer of the head and neck organs.

The incidence of cancers of the floor of the mouth remained practically unchanged. Conversely, there was an increase in the incidence of cancers of the tongue, other parts of the mouth, salivary glands, tonsil, nasopharynx, pear recess, laryngeal part of the throat, and other and unspecified sites within the lip, mouth, and throat. As a result, there was a decrease in the absolute number of cases to 286 for males in 2012 compared with 335 in 1990, with a minimal increase in the incidence for females (from 63 to 64). Overall, the incidence of cancers of the head and neck organs in Podkarpackie Voivodship in absolute numbers per year decreased, which resulted in a marked decline in the percentage share of the analysed group, compared with an increase in the incidence of malignant tumours overall $[12,13,15]$.

Conversely, (nationwide) there was a decrease in the incidence of cancers of the lip, oropharynx, nose, and middle ear, and a significant decrease in cancers of the larynx. At the same time, an increase was reported for the incidence of cancers of the tongue, gum, floor of the mouth, palate, other, and unspecified parts of the bottom of the oral cavity, salivary glands, tonsil, nasopharynx, recess pear, and nasopharynx, and other unspecified sites within the lip, mouth, and throat.

At the national level there was a decrease in the incidence of cancers of the lip, oropharynx, nose, and middle ear, and a significant decrease in the case of the larynx. At the same time, there was an increase in the incidence of cancers of the tongue, gum, floor of the mouth, palate, and other unspecified parts of the floor of the mouth, salivary glands, tonsil, nasopharynx, pear recess, and other and unspecified sites within the lip, mouth, and throat.

As a result, a moderate increase in the absolute number of cases of cancers of the head and neck organs was recorded in the analysed period, especially in the female population. It should be noted, however, that since 1993 the total incidence in absolute numbers has remained virtually at the same level [11, 12, 14, 16]. 


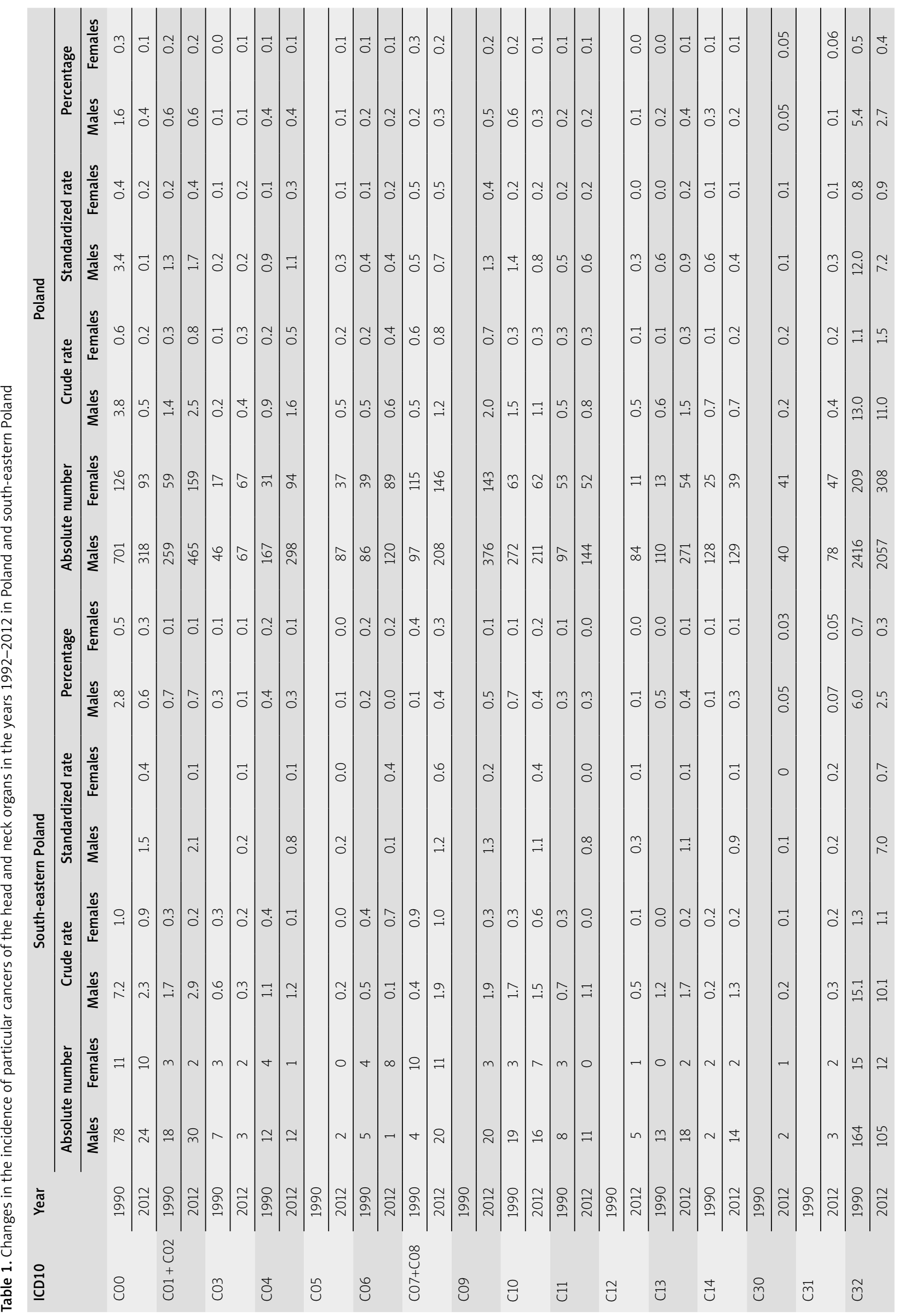




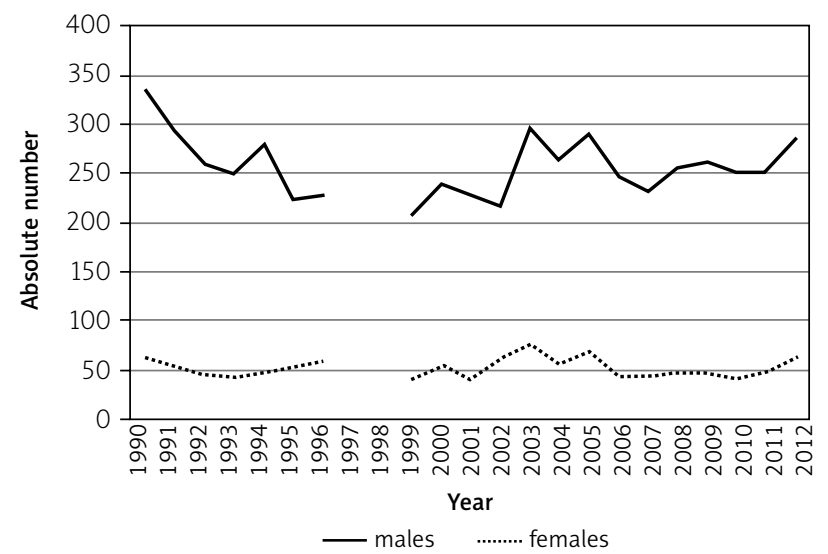

Fig. 1. Incidence of malignant tumours of the head and neck organs in south-eastern Poland in the years 1990-2012 (absolute numbers)

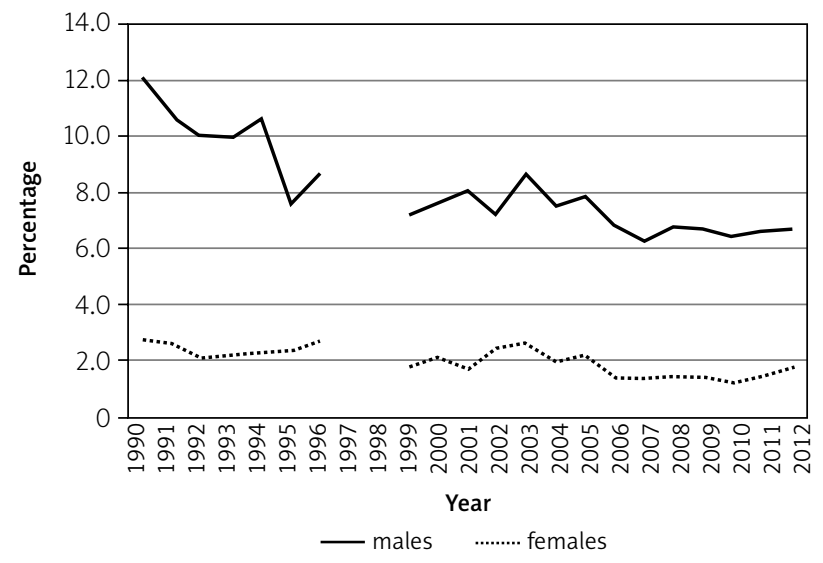

Fig. 3. Percentage share of malignant tumours of the head and neck organs in south-eastern Poland in the years 1990-2012

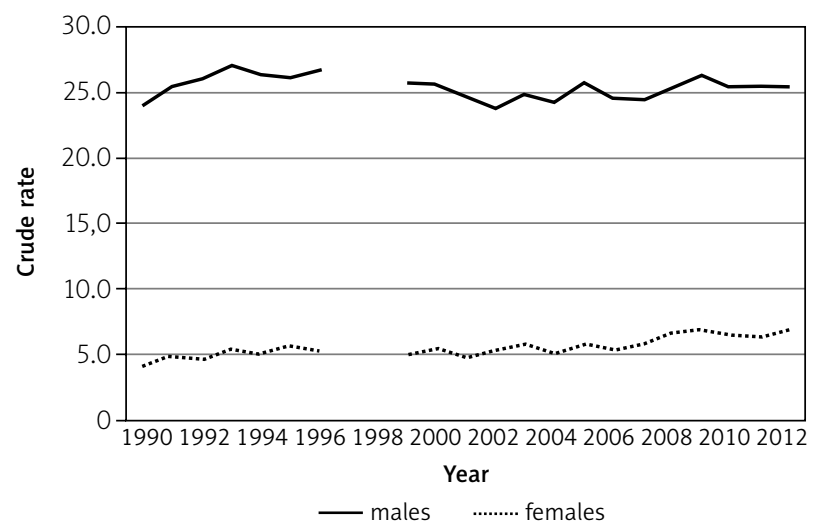

Fig. 5. Crude rates of incidence of malignant tumours of the head and neck organs in Poland in the years 1990-2012

The explanation of the changes may lie in the change in the impact of factors contributing to developing squamous cell cancers, which are the most common in this location. Classically, the primary carcinogenic factor for cancer of the upper respiratory tract is exposure to cigarette smoke. This phenomenon is particularly important for the most common cancer in this location, which is cancer of the larynx. A fall in the incidence of cancers of the oro-

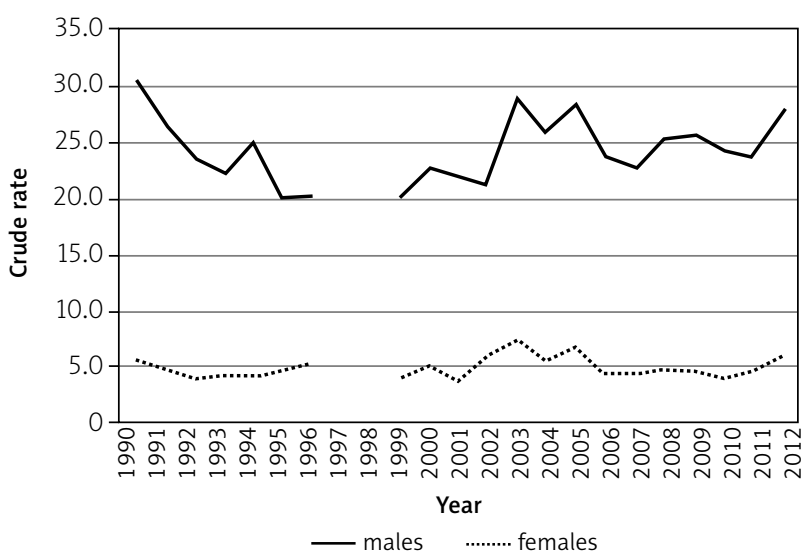

Fig. 2. Crude rates of incidence of malignant tumours of the head and neck organs in south-eastern Poland in the years 1990-2012

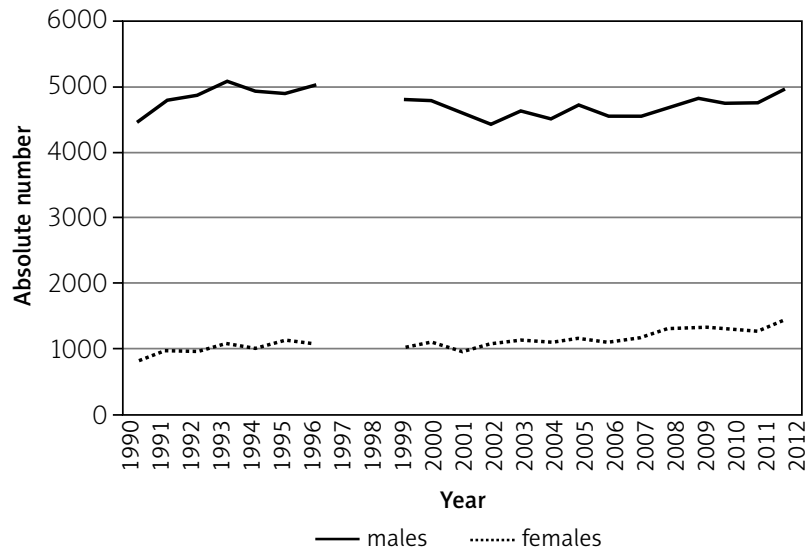

Fig. 4. Incidence of malignant tumours of the head and neck organs in Poland in the years 1990-2012 (absolute numbers)

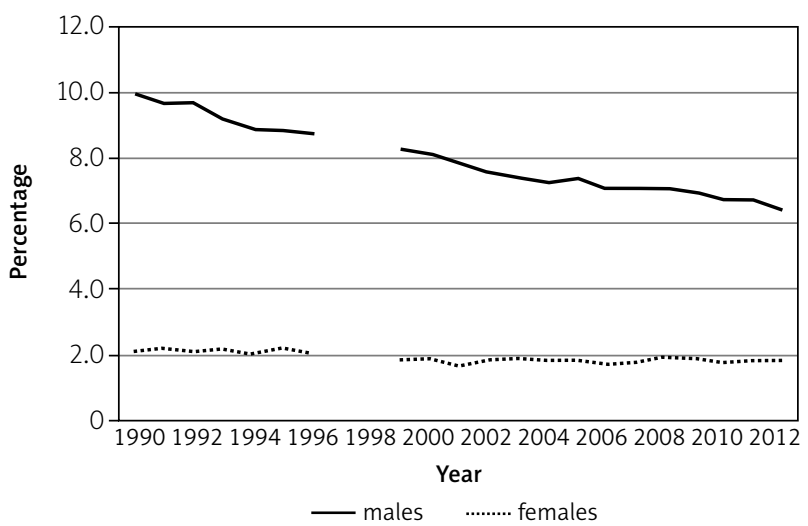

Fig. 6. Percentage share of malignant tumours of the head and neck organs in Poland in the years 1990-2012

pharynx according to ICD 10, which was recorded both in the country and in Podkarpackie Voivodship, is an apparent phenomenon. The ICD 10 classification is not in correlation with the anatomical definition of the oropharynx, commonly used in oncology. According to it, the scope of the oropharynx includes the tonsils, base (2/3 rear) of the tongue, palatal arches, soft palate, and the side and part of the back of the throat. While combining these locations, 


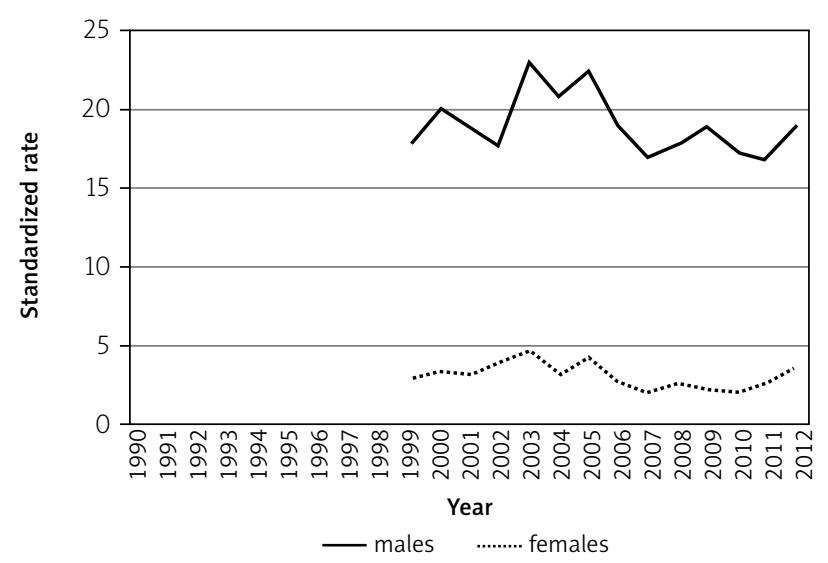

Fig. 7. Standardised rates of incidence of malignant tumours of the head and neck organs in south-eastern Poland in the years 19992012

which are considered separately by ICD 10, it is found that the total incidence of oropharyngeal cancers is significantly increasing, as is the case for cancers of the oral cavity, including the tongue, throat, and laryngeal part.

In fact, the incidence of cancers of the oropharynx defined anatomically, and not by ICD-10, is clearly increasing, which applies to both Podkarpackie Voivodship and the whole of Poland [11-16].

A comparative analysis of the incidence of cancers of the head and neck organs in Poland and in the current Podkarpackie Voivodship over the past decades indicates a clear trend of differences. Until the early 1990s the incidence rates were similar. However, in the past two decades, the incidence rates in Podkarpackie Voivodship have been clearly lower compared with the rest of the country. It is difficult to provide an explanation of this phenomenon. One cannot assume that the inhabitants of Podkarpacie Voivodship stop smoking more often than of the rest of the country, although it cannot be absolutely excluded.

An analysis of trends in smoking tobacco over the decades in the country shows that the percentage of smokers in Poland was highest in 1982 [17, 18].

For young and middle-aged men, this percentage was close to $70 \%$ at that time, and for women from these age groups it reached 50\% [19].

According to the literature, "compared with the countries of the European Union, Polish smokers were characterised by a high average number of cigarettes smoked daily (about 20 cigarettes for males and 15 cigarettes for women), long duration of smoking (about 20 years for males and 18 years for females) and a high percentage of persons having a dependence on tobacco (about 15\% according to the FTND index [Fagerström Test for Nicotine Dependence])" [20, 21].

A decreasing number of smokers reported in recent years may be the reason for a clear decrease in the incidence of cancer of the larynx, in particular, recorded both on a national scale, as well as in Podkarpackie Voivodship. At the same time, the number of cases of other tumours is growing, which can be due to different aetiology, including primarily HPV infection. HPV-dependent cancers concern mainly the oropharynx, followed by the mouth and

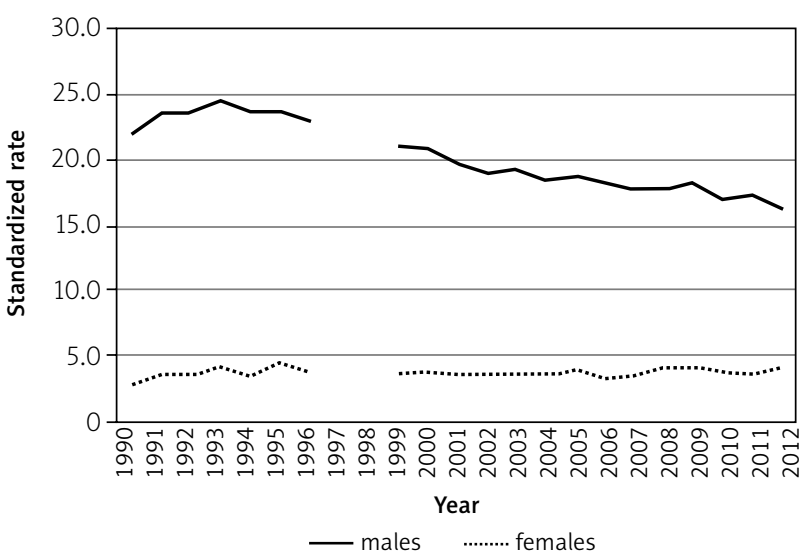

Fig. 8. Standardises rates of incidence of malignant tumours of the head and neck organs in south-eastern Poland in the years 19902012

laryngeal part of the throat. Among daily smoking men, a decrease in this proportion from 60\% in 1982 to $40 \%$ in 2000-2004 was observed for all age groups, with an annual downward trend of approximately $1 \%$ [22].

In the female population, the largest decline in daily smoking rate from $50 \%$ to $25 \%$ was recorded in the youngest age group of 20-29 years [22].

With regard to Podkarpacie, no such detailed data is available, although other relevant factors cannot be excluded.

Undoubtedly, the structure of industrialisation of Podkarpackie Voivodship has changed, as a result of the transformation of the political system, which could result in a reduction in environmental pollution. An example of these changes may be the reduction in the emission of particulate pollutants from factories that are particularly harmful by $84 \%$ (from 10,600 to 1699 tonnes per year) in the years 1996-2013 or in the emission of gaseous pollutants (including carbon dioxide from factories that are particularly harmful in tonnes) by $16 \%$ (from $3,830,306$ to 3,244,439 tonnes) [23].

Currently, there is no doubt that Podkarpackie Voivodship is one of the regions least exposed to these type of phenomena. The carcinogenic effect of environmental pollution in terms of the risk of cancers of the head and neck is not as remarkable as exposure to cigarette smoke, but it can clearly play an important role in this respect.

\section{In conclusions:}

1. Total incidence of HNCA has seen a slight upward trend in the absolute number of cases over the last two decades at the national level, with a reduction in the percentage share of this group among all malignant tumours at the same time.

2. At the national level, the increasing trend in the number of cases was considerably more strongly expressed for females than for males.

3. In the same period, a decrease in total incidence of HNCA was recorded in south-eastern Poland, both in absolute numbers, crude rate, and as a percentage share of the incidence of cancers. 
4. This trend was more strongly evident in a decline in the number of cases for males than for females, for whom a minimal growth was registered.

5. Both in the country and in south-eastern Poland a significant decrease in the incidence of cancer of the larynx was reported, with an increase in the incidence of oropharyngeal cancer at the same time - with regard to the anatomical definition of this cancer.

The authors declare no conflict of interest.

\section{References}

1. Kawecki A, Nawrocki S. Nowotwory nabłonkowe narządów głowy i szyi. In: Zalecenia postępowania diagnostyczno-terapeutycznego w nowotworach złośliwych. Krzakowski M, Warzocha K (ed.). Wydawnictwo Via Medica, Gdańsk 2013.

2. Kawecki A. Nowotwory jamy ustnej, gardła i krtani - zapomniany problem. In: Wybrane problemy onkologii. Towpik E (ed.). Wydawnictwo Domena, Warszawa 2015.

3. Hashibe M, Brennan P, Shu-chun Chuang, Boccia S. Interaction between tobacco and alcohol use and the risk of head and neck cancer: pooled analysis in the INHANCE consortium. Cancer Epidemiol Biomarkers Prev. 2009; 18: 541-50.

4. Castellsagué X, Quintana MJ, Martínez MC, et al. The role of type of tobacco and type of alcoholic beverage in oral carcinogenesis. Int J Cancer 2004; 108: 741-9.

5. Mashberg A, Boffetta P, Winkelman R, Garfinkel L. Tobacco smok ing, alcohol drinking, and cancer of the oral cavity and oropharynx among U.S. Veterans Cancer. Cancer 1993; 72: 1369-75.

6. Franceschi S, Talamini R, Barra S, Barón AE, Negri E, Bidoli E, Serraino D, La Vecchia C. Smoking and drinking in relation to cancers of the oral cavity, pharynx, larynx, and esophagus in northern Italy. Cancer Res 1990; 50: 6502-7.

7. Kreimer AR, Clifford GM, Boyle P, Franceschi S. Human papillomavirus types in head and neck squamous cell carcinomas worldwide: a systematic review. Cancer Epidemiol Biomarkers Prev 2005; 14: 467-75.

8. Kim L, King T, Agulnik M. Head and neck cancer: changing epidemiology and public health implications. Oncology (Williston Park) 2010; 24: 915-9, 924

9. D'Souza G, Kreimer AR, Viscidi R, Pawlita M, Fakhry C, Koch WM, et al. Case-control study of human papillomavirus and oropharyngeal cancer. N Engl I Med 2007; 356: 1944-56.

10. Kreimer AR, Alberg AJ, Daniel R, Gravitt PE, Viscidi R, Garrett ES, Shah KV, Gillison ML. Oral human papillomavirus infection in adults is associated with sexual behavior and HIV serostatus. I Infect Dis 2004; 189: 686-9.

11. Wojciechowska U, Didkowska J, Zatoński W. Nowotwory złośliwe w Polsce w 2012 roku. Centrum Onkologii - Instytut im. Marii Skłodowskiej-Curie, Warszawa 2014.

12. Gawełko J. Zachorowania na nowotwory złośliwe w regionie Polski południowo-wschodniej w latach 1963-2010. Wydawnictwo UR, Rzeszów 2016

13. Grądalska-Lampart M, Radziszewska A, Patro A, Gawełko J. Nowotwory złośliwe w województwie podkarpackim w 2012 roku. Rzeszów 2014.

14. Didkowska J, Wojciechowska U, Zatoński W. Nowotwory złośliwe w Polsce w 2011 roku. Centrum Onkologii - Instytut im. Marii Skłodowskiej-Curie, Warszawa, 2013.

15. Grądalska-Lampart M, Radziszewska A, Patro A, Gawełko J. Nowotwory złośliwe w województwie podkarpackim w 2011 roku. Rzeszów 2014.

16. Śledź J. Nowotwory jamy ustnej - dane epidemiologiczne i czynniki ryzyka zachorowania. Biul Wydz Farm WUM, 2015; 2: 6-12.

17. Forey B, Hamling J, Lee P, Wald N. International Smoking Statistics. $2^{\text {nd }}$ ed. A Collection of Historical Data from 30 Economically De- veloped Countries, The Wolfson Institute of Preventive Medicine, Oxford, U.K. 2002; 511-33.

18. Gilmore A, Pomerleau J, McKee M, Rose R, Haerpfer CW, Rotman D, Tumanov S. Prevalence of smoking in 8 countries of the former soviet union: results the living conditions, lifestyles and health study. Am J Public Health. 2004; 94: 2177-87.

19. Zatoński W. Tobacco Smoking in Central European Countries: Poland. In: Boyle P, Gray N, Henningfield J, Seffrin J, W. Zatonski W (eds.). Tobacco and Public Health: Science and Policy. Oxford University Press, Oxford, N.Y. 2004; 235-25.

20. Boyle P, Gandini S, Robertson C, Zatonski W, Fagerström K, Slama K, Kunze M, Gray N. and the International Smokers Survey Group, Characteristics of 10,295 smokers in representative samples from 17 European countries. Eur J Public Health 2000; 10: 5-14.

21. Fagerström KO, Kunze M, Schoberberger R, Breslau N, Hughes JR, Hurt RD, Puska P, Ramström L, Zatoński W. Nicotine dependence versus smoking prevalence: comparisonamong countries and categories of smokers. Tob Control 1996; 5: 52-6.

22. Zatoński W, Przewoźniak K, Gumkowski J. Palenie tytoniu w Polsce - obraz, zjawiska, nowe trendy i wyzwania. In: Jaworski R (ed.). Palenie tytoniu - aspekty medyczne, psychicznei duchowe. Płocki Instytut Wydawniczy, Płock 2006; 111-20.

23. Portal GUS, Bank Danych Lokalnych (Dziedzinowa Baza Wiedzy.) Available at: http://stat.gov.pl (3.11.2015).

\section{Address for correspondence}

\section{Jan Gawetko}

Al. mjr. W. Kopisto 2 A

35-310 Rzeszow, Poland

e-mail: jangawelko@02.pl

Submitted: 15.09 .2016

Accepted: 11.11.2016 